\title{
Evaluation of induced vertical stress during depillaring in blasting gallery panel workings
}

\author{
Inumula Satyanarayana ${ }^{1}$ and Gnananandh Budi ${ }^{2^{*}}$
}

\author{
* Correspondence: \\ anandbudi@gmail.com \\ ${ }^{2}$ Department of Mining \\ Engineering, Indian School of \\ Mines, Dhanbad 826004, India \\ Full list of author information is \\ available at the end of the article
}

\begin{abstract}
Background: Selection of a suitable mining method for extraction of a thick coal seam with optimal recovery and safety is an extremely delicate process. In fact, single lift working of full thickness of a thick coal seam has always a verge over the multi-slice working due to favorable economics and high production and productivity. Blasting Gallery (BG) method is suitable for extraction of virgin thick seams as well as developed pillars in thick seams in single lift. The method was very successful resulting in $85 \%$ of extraction with high productivity. But, this method experienced strata control problems during final extraction. The presence of strong and massive overlying roof strata caused high values of the mining induced stress over the pillars facing the goaf line during the depillaring. High values of mining-induced stresses in and around a depillaring face of thick coal seam generally create a threat of pillar overriding.
\end{abstract}

Methods: This paper describes the assessment of mining induced vertical stress in a BG panel during depillaring in specific geomining conditions, together with the results of the laboratory and field investigations. The attempt was based on field monitoring data of depillaring faces in BG panel of Godavari Khani (GDK) No 10 Incline, Singareni Collieries Company Ltd. (SCCL). Based on the results of laboratory investigations on simulated (FEM) models using ANSYS software, the numerical simulation (FEM) results are validated with field investigation results. The safety factor of the pillar is evaluated using Hoek and Brown failure criterion at different advances of goaf edge.

Results and conclusions: The research revealed that the width of abutment zone is estimated to be about $35 \mathrm{~m}$ to $40 \mathrm{~m}$ from the diagonal line of extraction in the BG panels and the induced vertical stress and roof deformation decreases as one goes away from the goaf edge. It was observed that the safety factor of the pillar decreases when line of extraction moves towards center of the pillar. Results of finite element analysis using ANSYS are validated with the strata monitoring instrumentation data in the BG 2B panel of GDK No. 10 Incline, SCCL.

Keywords: Thick seam coal mining; Blasting Gallery Method; Mining induced stress; Field monitoring; Safety factor

\section{Introduction}

Coal is one of the major natural resources to meet the growing energy demand in India due to its proven geological reserve. About $93 \%$ of underground production is achieved by Bord \& Pillar method, mostly by conventional hand section with a low productivity of about 0.87 tonnes per man shift. Bord and pillar is also known as room and pillar mining system in which the mined material is extracted across a horizontal plane while leaving "pillars" of untouched material to support the overburden leaving open areas

\section{Springer}

(c) 2015 Satyanarayana and Budi; licensee Springer. This is an Open Access article distributed under the terms of the Creative Commons Attribution License (http://creativecommons.org/licenses/by/2.0), which permits unrestricted use, distribution, and reproduction in any medium, provided the original work is properly credited. 
or "rooms" underground. It is usually used for relatively flat-lying deposits, such as those that follow a particular stratum. In general practice, the size of both room and pillars are kept almost equal, while in Bord \& Pillar, pillar size is much larger than bord (gallery). The room and pillar system is used in mining coal, iron and copper ores mainly when found as blanket sediments, stone and aggregates, talc, soda ash and potash.

About 3000 million tonnes of coal is locked up in standing pillars (Dixit and Mishra 2010) under varying geo-mining conditions, which is prime target of the mining industry to meet the demand of coal production. Present pillar extraction (depillaring) practices of the country have, predominantly, adopted intermediate mechanisation along with few fully mechanised depillaring faces. Most of these faces are operating at shallow cover. But the existing technoeconomical conditions of the industry are attracting a fully mechanised depillaring system for deep seated coal pillars, which is likely to grow in near future (Singh et al. 2011a). In Singareni Collieries Company Ltd. (SCCL), about 60\% of coal is locked up in standing pillars formed by Bord and Pillar method (Internal Reports on BG method in the SCCL). About $50 \%$ of coal reserves in India are in seams thicker than $4.5 \mathrm{~m}$, which come under the category of thick seams, the exploitation of which is consistently posing challenges to the mining engineers. Extraction of thick seams by conventional hand section method is neither productive nor effective from the conservation point of view (heavy loss of coal by conventional hand-section method). The percentage of extraction by hand section mining in thick seams is as low as $25-30 \%$.

In order to achieve higher percentage of extraction (70-85\%) and to overcome the problems in the extraction of thick seams by conventional bord and pillar method, the Charbonnage de France (CdF) suggested the Blasting Gallery (BG) method for extraction of virgin thick seams as well as developed pillars in thick seams in India. It is a variant of the bord and pillar method of mining. Safe and efficient underground extraction of coal pillars under competent roof strata needs information about amount and nature of the mining induced vertical stress over pillars in and around the Blasting Gallery (BG) panel workings. However, the performance of these workings is highly dependent upon two types of stresses; mining induced stresses (Singh et al. 1996) and in situ stress (Sheorey 1994). For a given site, the in situ stress is more or less static in nature but the mining induced stresses over pillars/stooks keeps changing and is highly influenced by the strata equilibrium dynamics during different stages of the underground coal mining activity. Accidents due to movement of strata in underground coal mines had been a major concern for the mining industry and it is largest contributing factor of underground coal mine accidents. Continuous efforts were being made by all concerned to reduce the hazard of strata movement. The condition of strata and the stress environment around any working place is always dynamic in nature. No two working places are having identical strata condition. It is therefore essential to assess the roof condition of the underground working places at regular intervals by engineering methods. State-of-art of monitoring system through instrumented rock bolts, tell-tales, multiple point borehole extensometers, convergence indicators, load cells etc. are available for continuous monitoring the strata movement.

Due to complex rock mass behavior under changing stress conditions of underground coal mining, an empirical formulation on the basis of field observations is, generally, adopted for assessment of nature and amount of mining induced stress development. In this paper, results of the field study in SCCL mine are assessed and an attempt is made to 
validate the FEM results with field investigation results to assess ultimate value and range of the mining induced vertical stress along depillaring face of line of extraction.

\section{Blasting gallery method}

Blasting Gallery (BG) method of extraction of thick seams having a gentle gradient proved to be most successful from the point of view of percentage of extraction as well as safety and mechanization. The basic principle of this method is to recover the coal of thick seam by drilling and blasting around galleries (rooms) located in the bottom of the seam and placed at regular intervals (Figure 1). The width of the pillar left between two adjacent rooms is between 8 to $15 \mathrm{~m}$. Holes of 10 to $12 \mathrm{~m}$ long are drilled in fan cut pattern around galleries at regular intervals of 1 to $1.5 \mathrm{~m}$ with an angle inclined towards goaf by means of crawler mounted jumbo drill. Blasting is made with permitted (P-3) explosives separated by plastic spacers and detonating fuse (G-cord). Loading is carried out by $3 \mathrm{~m}^{3}$ bucket capacity remote controlled Load Haul Dumpers (LHDs) which discharge coal on to armoured chain conveyor (ACC) fitted with Lump Breaker to crush the coal to less than $200 \mathrm{~mm}$ size. These armoured chain conveyors feed the coal on to belt conveyor network which transport coal to surface. All rooms are supported by RS Joists placed over a pair of open circuit hydraulic props at 1 to $1.5 \mathrm{~m}$ interval (Hanjura 2002).

The SCCL adopted this method in the year 1989 at Godavari Khani (GDK) No. 10 Incline for extraction of coal in virgin area. The method was very successful resulting in $85 \%$ of extraction with high productivity. After that, SCCL initiated such method in another three mines. Realizing the rate of success in such mines, BG method of extraction is gearing up its future potentiality. The main advantages of BG method are higher percentage of extraction and amenability to use in seams already developed by Bord and Pillar method in one or two sections. The BG method worked successfully in three mines of SCCL for seams ranging from $7 \mathrm{~m}$ to $11 \mathrm{~m}$. In favourable geology, moderate depth and freshly developed workings, the results have been excellent, averaging production of more than 1000 tonnes/day.






\section{Mining induced stress}

In virgin condition, a coal seam is nearly uniformly stressed by the dead weight of the overlying strata. When an opening is made in the coal seam, the strata equilibrium condition is disturbed and stress distribution takes place to reach another state of equilibrium. Here, a distressed zone occurs in the roof of the opening and the stress over the excavated area is shifted into the neighboring solid coal pillars resulting in an increase in overall stress over the solid coal pillars. This increase in stress over neighboring solid coal pillars due to the opening is called mining induced stress and has got two components: vertical and horizontal. As per our experiences of different strata control investigations in field, it is mostly vertical mining induced stress, which influences stability of underground structures. Before roof failure, the amount of the transferred overburden load due to an opening is mainly dependent upon its width and depth cover of the seam (Hoch et al. 1991). In general, the surrounding pillars experience a maximum amount of mining induced stress just before the main fall of the roof.

In general, tributary area method is used to estimate the value of mining induced stress around a symmetrical excavation with low percentage of extraction. The scope of the tributary area method ends with high percentage of extraction and roof strata failure. Once the strata breaks and acquires a new state of equilibrium, an assessment of mining induced stress over coal pillars around the excavation becomes a challenging task. In fact, failure of overlying roof strata is mainly governed by the geology and strength of the strata. Due to further dimensional increase of the opening, mining induced stress is created by the immediate roof strata cantilevering over the goaf area and their magnitudes depend, mainly, on the length and thickness of the roof strata that overhang inside the goaf area. In past, a number of attempts (Sellers 1997; Majumder and Chakrabarty 1991) utilizing, both, simulation (Jaiswal et al. 2004; Mathur 1992) and field observations (Maleki 1992; Gale 1998) were made to understand the nature and amount of mining induced stress variation in and around an underground excavation due to coal mining. Jayanthu et al. (2004) found that the maximum vertical stress over rib and stook decreases with increase in working height during depillaring. Field investigations (Singh et al. 1996) showed that the nature of development of mining induced stress over pillar/stook at different stages of depillaring, for a nearly flat coal seam, is influenced by different parameters like depth of cover, characteristics of overlying strata, distance from face line, extraction height and goaf treatment.

Competency of our coal and rock masses supports favourable geo-mining conditions of Indian coalfield for the development of a coal seam. However, depillaring encounters strata control problems due to competent overlying strata. An estimation of amount and range of influence of mining induced stress provides considerable help in optimizing, both, natural and applied support (Singh et al. 2011b). The safety of a coal pillar involves its strength and stress over the pillar. CIMFR has developed (Sheorey 1992) empirical relationship to estimate pillar strength, which is given as:

$$
S=0.27 \sigma_{c} h^{-0.36}+\frac{H}{150}\left(0.6+\frac{150}{H}\right)\left(\frac{W}{h}-1\right) M P a
$$

where $S$ is the strength of pillar, $\sigma_{c}$ is the compressive strength of one $2.5 \mathrm{~cm}$ cube of coal (MPa), $h$ is the extraction height (m), $H$ is the depth of cover (m) and $W$ is the pillar width (m). 
However, there is a lack of a reliable norm to estimate mining induced stresses, in and around a depillaring face, which makes it difficult to assess the safety factor. An underground pillar extraction process experiences complex nature of strata equilibrium dynamics and, therefore, an estimation of mining induced stress can be done either through field monitoring using instruments like stress meter or by simulation study.

\section{Field investigations}

The mining industry is the most hazardous one and mining operations becoming gradually more and more difficult day by day with the increasing depth of mining and winning of thick as well as complex deposits in more adverse geo-mining conditions. This situation demands close observation of strata behaviour in and around the workings especially in dynamic operations like depillaring operations in coal mines (Mandal et al. 1998). Strata behaviour investigations were conducted in the BG panels to understand the geomechanical behaviour of the pillars facing goaf line and at the face and the development of induced stress during the pillar extraction. These investigations are aimed at measuring the location and magnitude of the front abutment and the deformation of the strata surrounding the pillars facing goaf line, using geotechnical instruments. It is well established that the behaviour of the strata in BG panels can be properly understood by measuring the various diagnostic parameters such as the stress on pillars, bed separation and convergence in galleries and load on the supports. Behaviour of strata during depillaring in the panel was monitored with the help of stress meters, multi point borehole extensometers (MPBX), convergence indicators and load cells. The instruments were installed at difference locations in the panel to study the behaviour of strata during depillaring. Table 1 presents the details of the instruments installed in the BG panel.

\section{Details of study site (BG 2B panel of GDK No.10 incline)}

The GDK No. 10 Incline was situated in the South-Eastern part of Ramagundam Coal Belt. The coal formations of Ramagundam are of Kamthi and Barakar series. The gradient of the mine is varying 1 in 5 to 1 in 7 . SCCL adopted the BG method to extract the complete thickness of about $10.5 \mathrm{~m}$ No. 3 seam in one lift. The strata overlying the coal seam are composed of fine to medium coarse grained sandstone with carbonaceous shale bands and carbonaceous sandstones. The compressive strength of the coal roof varies from $221-246 \mathrm{~kg} / \mathrm{cm}^{2}$. The borehole section No.441, GDK No.10 of SCCL is presented in Figure 2. The Rock Mass Rating (RMR) of the immediate coal roof in No. 3 seam is 59.90 (Internal Reports on BG method in the SCCL). No.3 seam of $11.5 \mathrm{~m}$ thickness of GDK No.10 incline was developed by conventional board and pillar method and depillared by

Table 1 Details of instruments installed in the BG panel

\begin{tabular}{llll}
\hline Sl. no. & Instrument & Parameter monitored & Accuracy \\
\hline 1 & Stress Cells (Vibrating Wire type) & Change in stress over pillar/stook & $0.002 \mathrm{MPa}$ \\
2 & Load cell (Vibrating Wire type) & Change in load over the support & $0.001 \mathrm{ton}$ \\
3 & Multi-point Bore hole Extensometer & Bed Separation at different horizons & $0.2 \mathrm{~mm}$ \\
& (Vibrating Wire type) & & $0.5 \mathrm{~mm}$ \\
\hline
\end{tabular}




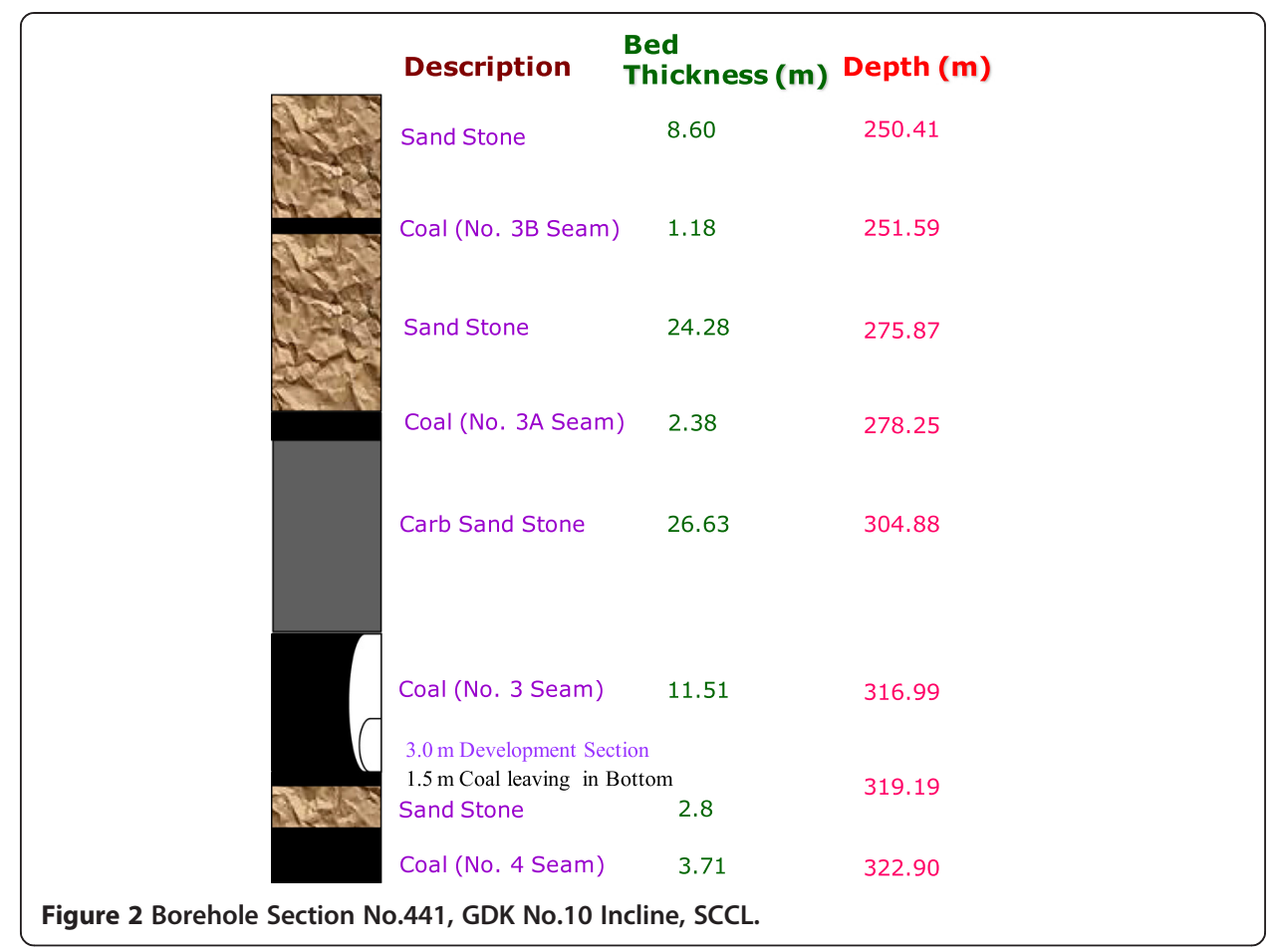

Blasting Gallery method. The BG 2B panel was developed along the floor leaving around $1.5 \mathrm{~m}$ thickness of coal in the bottom. There is a shale layer of about $0.5 \mathrm{~m}$ thick at $3 \mathrm{~m}$ height above floor of the seam. The permission was given for a maximum height of $3 \mathrm{~m}$ during development. So, the development was made leaving around $1.5 \mathrm{~m}$ thickness of coal in the bottom to remove the weak shale layer in the roof for stability of galleries. The left-over $1.5 \mathrm{~m}$ thick coal in the bottom was extracted during depillaring. The width and height of galleries in the bottom section were $4.2 \mathrm{~m}$ and $3 \mathrm{~m}$ respectively. This panel was partially extracted due to spontaneous heating as big stooks are left inside the goaf. The process of self-heating of coal or other carbonaceous material without an external heat source resulting eventually in its ignition is termed as "spontaneous heating" or "auto oxidation". The spontaneous heating of coal occurs when sufficient oxygen is available to sustain the low temperature reaction of coal with oxygen but the heat produced by the coal oxidation is not adequately dissipated by conduction or convection. The rate of oxidation increases as the temperature increases. The salient features of $\mathrm{BG} 2 \mathrm{~B}$ Panel are shown in Table 2.

Four coal seams namely 3B, 3A, 3 and 4 (in descending order) out of which only 3 and 4 seams are workable in GDK No. 10 Incline. The coal measures are trending in E-W direction on the southern side and swinging towards N-W in the northern part of the block. The borehole section of GDK No. 10 Incline is shown in the Figure 2.

\section{Stress induced in the pillar/stook}

In order to know the variation of stress over the pillars/stooks due to depillaring operations, five vibrating wire stress meters were installed at pre-determined locations in BG 2B Panel. These stress meters were installed inside the original/split pillars through a horizontally drilled hole. Each stress meter was installed into the pillar at an approximate 
Table 2 Salient features of BG 2B panel

\begin{tabular}{ll}
\hline Size of panel & $135 \mathrm{~m} \times 150 \mathrm{~m}\left(17000 \mathrm{~m}^{2}\right)$ \\
No. of pillars & 12 \\
No. of rooms & 9 \\
Minimum \& maximum depth & $300 \mathrm{~m} \& 322 \mathrm{~m}$ \\
Total coal in the panel & 250840 tonnes \\
Extractable coal in the panel & 191280 tonnes \\
Extracted Area & $10066 \mathrm{~m}^{2}$ \\
Panel started on & 29.07 .2002 \\
Panel closed on & 18.01 .2003 \\
Gradient & 1 in 5.5 to 1 in 6 \\
Working thickness & $10.5 \mathrm{~m}$ \\
Overlying workings & Overlying 1 seam had been exploited and 2 seam was virgin. \\
Underlying workings & Underlying 4 seam was virgin \\
\hline
\end{tabular}

depth of 6-8 $\mathrm{m}$ (Figure 3). The instrumentation plan of BG 2B Panel showing location of different instruments is shown in Figure 4. The first stress meter was installed in the dipside pillar at 63LN/38D, when it was $70 \mathrm{~m}$ away from line of extraction. The maximum stress induced in the pillar and the corresponding average rate of change in stress over a period of 75 days were $48.29 \mathrm{~kg} / \mathrm{cm}^{2}$ and $0.635 \mathrm{~kg} / \mathrm{cm}^{2}$ per day respectively at $5.5 \mathrm{~m}$ away from goaf line. The stress was relaxed to $9.94 \mathrm{~kg} / \mathrm{cm}^{2}$ after 4 days of induced fall. The maximum change observed in a day was $1.51 \mathrm{~kg} / \mathrm{cm}^{2}$. The second stress meter was installed in rise-side pillar at 61ALN/38D when it was $54 \mathrm{~m}$ away from line of extraction. The maximum stress induced in the pillar and the corresponding rate of change in stress were $8.65 \mathrm{~kg} / \mathrm{cm}^{2}$ and $0.39 \mathrm{~kg} / \mathrm{cm}^{2} /$ day respectively in 22 days at $48 \mathrm{~m}$ away from goaf line. The stress was relaxed to $5.61 \mathrm{~kg} / \mathrm{cm}^{2}$ after 3 days of induced fall and again increased to $7.68 \mathrm{~kg} / \mathrm{cm}^{2}$ on the next day at $44 \mathrm{~m}$ away from goaf line. The maximum change in a day was $1.27 \mathrm{~kg} / \mathrm{cm}^{2}$. The third stress meter was installed at 65LN/39D in the dip-side barrier at a distance of $41 \mathrm{~m}$ from the edge of goaf. The stress was increased gradually and the rate of change in stress was almost stable except slight variations in the initial days. The measured stress was $7.23 \mathrm{~kg} / \mathrm{cm}^{2}$ and the rate of change in stress was $0.14 \mathrm{~kg} / \mathrm{cm}^{2}$ per day. The fourth stress meter was installed at $65 \mathrm{LN} / 38 \mathrm{D}$ in the dip-side barrier when the goaf edge was $98 \mathrm{~m}$ away from the monitoring station. The increase in stress was continued at a rapid rate. The maximum change in stress in a day was $1.96 \mathrm{~kg} / \mathrm{cm}^{2}$. The induced stress over the pillar was $28.63 \mathrm{~kg} / \mathrm{cm}^{2}$ and the rate of change in stress was $0.55 \mathrm{~kg} / \mathrm{cm}^{2}$ per day. The fifth stress meter was installed in dip-side pillar at 61ALN/38D when it was $41 \mathrm{~m}$ away from line of extraction. The maximum stress induced in the pillar and the corresponding rate of change in stress were $8.52 \mathrm{~kg} / \mathrm{cm}^{2}$ and

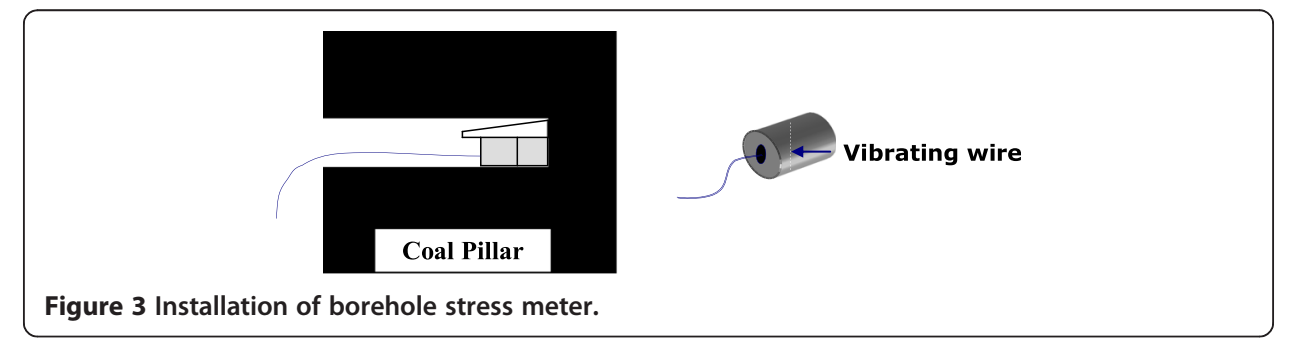






$0.17 \mathrm{~kg} / \mathrm{cm}^{2}$ per day respectively in 49 days at $9.5 \mathrm{~m}$ away from goaf line. The maximum change in a day was $1.55 \mathrm{~kg} / \mathrm{cm}^{2}$ when goaf edge distance was $9.5 \mathrm{~m}$. The ups and downs in the early days were the consequence of induced and natural falls. The graphs showing the mining induced stress variations at 63ALN/38D and 61ALN/38D locations in this panel are shown in Figures 5 and 6 respectively.

The stress capsules were installed in middle pillars of each panel to know the development of mining induced vertical stress as the extraction progresses. The change in measured stress and rate of change in stress are little more in BG 2B panel due to leaving of big stooks in the goaf. In other panels, the change in measured stress and rate of change in stress are less which indicates the stability of pillars ensuring the safety. The stress meter is installed at 65LN/38D in the dip-side barrier when the goaf edge is $98 \mathrm{~m}$ away from the monitoring station. The increase in stress is continued at a rapid rate. The ups and downs in readings during the early days are the consequence of induced and natural falls. The maximum change in stress in a day is $1.96 \mathrm{~kg} / \mathrm{cm}^{2}$. The measured stress over the pillar is $28.63 \mathrm{~kg} / \mathrm{cm}^{2}$ and the rate of change in stress is $0.55 \mathrm{~kg} / \mathrm{cm}^{2}$ per day (Figure 7).

In $65 \mathrm{AL} / 40 \mathrm{D}$ level, the measured deformation and the rate of deformation were $9 \mathrm{~mm}$ and $0.14 \mathrm{~mm}$ per day respectively. Maximum deformation of $0.5 \mathrm{~mm}$ in consecutive two days was measured before natural fall (Figure 8).



Figure 5 Observation of stress at 63ALN/38D in BG 2B Panel, GDK No.10 Incline. 


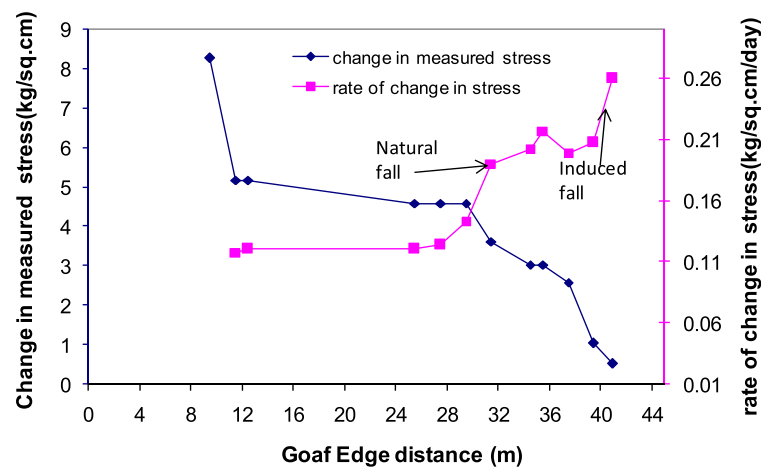

Figure 6 Observation of stress at 61ALN/38D in BG 2B Panel, GDK No.10 Incline.

The analysis of stress in different panels at GDK No.10 Incline are presented in Table 3.

From the field investigations results, it was observed that the intensity of abutment loading was negligible with a variation of about $0.6 \mathrm{~kg} / \mathrm{cm}^{2}$ stress over the pillars/stooks within $15 \mathrm{~m}$ in advance of the line of extraction. Higher stress conditions which were anticipated due to increased depth cover, were not noticed in these panel. This may be because of the distressing effect caused as a result of the settled goaf overlying the parting of about $65 \mathrm{~m}$ between 1 and 3 seams. Stress meter at a distance of about $60 \mathrm{~m}$ from the diagonal line of extraction indicated no perceptible variation of stress over pillar. Maximum variation of stress was about $1.51 \mathrm{~kg} / \mathrm{cm}^{2}$ when the monitoring station was about $5.5 \mathrm{~m}$ from goaf edge indicating negligible abutment loading on the advance pillars at this juncture. Although the value of maximum vertical stress, generally, increased with the decrease in its distance from the goaf line, the trend of variation was observed to be quite different for different types of overlying roof strata. The rate of change in stress was observed to be more for grey sandstone when compared to carbonaceous sandstone. The peak of the vertical stress was observed to be governed by the movement of the roof strata which is evident from the Figure 6. When the rate of stress was $0.26 \mathrm{~kg} / \mathrm{cm}^{2} /$ day, the induced blasting was done in the roof to release the stress by slowing down dynamic movement of strata. The rate of stress comes down to $0.11 \mathrm{~kg} / \mathrm{cm}^{2} /$ day from $0.19 \mathrm{~kg} / \mathrm{cm}^{2} /$ day after natural fall because of reduced movement

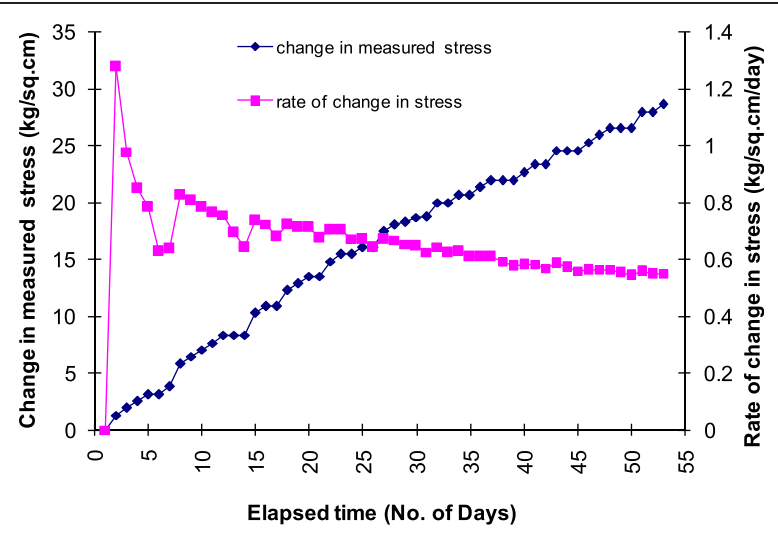

Figure 7 Observation of stress variation in the dip-side barrier pillar with time at 65LN/38D. 


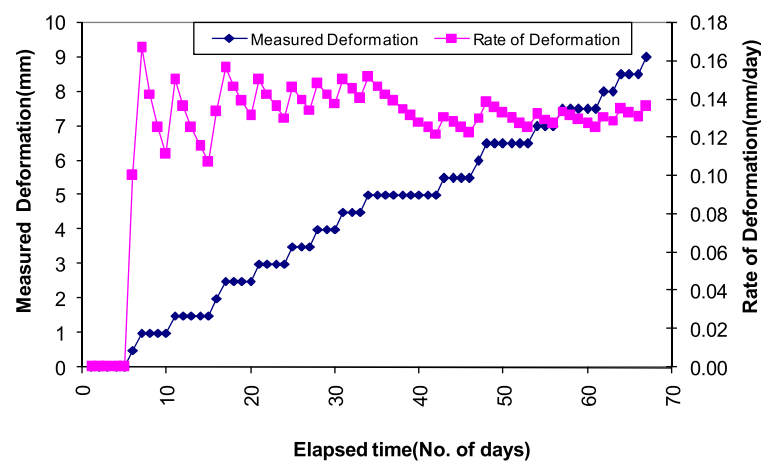

Figure 8 Observance of deformation at 65AL/40D with time.

of strata. From the field data analysis, it was observed that the value of mining induced stress increased with decrease in its distance from the face position but maximum value of mining induced vertical stress was observed during roof falls only.

\section{Numerical modelling}

With the rapid advancement of computer hardware technology in the last two decades, the use of numerical modelling software as a design tool in geotechnical engineering has become both affordable and popular. Their application has gradually changed from predominantly experimental research to practical engineering design. Methods like finite elements, boundary elements and distinct elements have all been used extensively in the design and analysis of geotechnical structures. The Finite Element Method (FEM) is an efficient tool available to the mine planners and designers for evaluation and prediction of rock mass response. This would help the decision making process for a suitable, economic and operationally feasible mining option (Sjaberg 1983).

ANSYS is a finite element modelling and analysis tool to solve the underlying governing equations and the associated problem-specific boundary conditions (ANSYS 80 User s Guide). It is always preferred to investigate the depillaring problem in a threedimensional simulated model because depillaring is, basically a three-dimensional problem. But many items, the broken and jig-jag nature of the depillaring face becomes too complex to correctly simulated even in a three dimensional model. It is clearly due to the vastness of the problem, as the bigger model consumes more time and computer resources, which is likely to increase by a factor of 10 or more in going from two to three dimensions. With this consideration, simple two dimensional case of the geo-mining conditions of the sites were simulated to understand development of mining induced stress ahead of a depillaring face and the variation of safety factor of the pillar (facing goaf line) (Singh 2004).

Table 3 Stress analysis of different panels at GDK No.10 Incline

\begin{tabular}{|c|c|c|c|c|c|}
\hline Panel & Depth (m) & $\begin{array}{l}\text { Maximum measured } \\
\text { stress }\left(\mathrm{kg} / \mathrm{cm}^{2}\right)\end{array}$ & $\begin{array}{l}\text { Maximum rate of change } \\
\text { in stress }\left(\mathrm{kg} / \mathrm{cm}^{2} / \text { day }\right)\end{array}$ & $\begin{array}{l}\text { Maximum stress } \\
\text { in a day }\left(\mathbf{k g} / \mathrm{cm}^{2}\right)\end{array}$ & $\begin{array}{c}\text { Distance from line } \\
\text { of extraction }(\mathrm{m})\end{array}$ \\
\hline$B G 2 B$ & 311 & 48.29 & 0.635 & 1.51 & 5.5 \\
\hline BG $2 C$ & 307 & 3.63 & 0.242 & 1.69 & 22 \\
\hline$B G 2 D$ & 311.5 & 9.84 & 0.09 & 0.77 & 40 \\
\hline
\end{tabular}


For the purpose of numerical modeling, the Hoek-Brown failure criterion was used to estimate the safety factor of the coal pillar. For numerical modeling, density, compressive strength and Young's modulus of overlying strata are obtained from borehole data (Table 4). The RMR value of roof rock is 65 and the compressive strength of coal is $22.9 \mathrm{MPa}$. The material constant for rock mass, $\mathrm{m}_{\mathrm{i}}$ is 19 for sandstone which covers most of the overlying strata. The major and minor principal stresses obtained from numerical analysis have been used as input parameters in the modified Hoek-Brown failure criterion. In this study, Hoek-Brown criterion was selected as compared to Mohr's criterion because Mohr's criterion does not take into account of the joint condition of the rock which is being taken care by the Hoek-Brown criterion (Hoek and Brown 1997). The original Hoek-Brown failure criterion (Hoek and Brown 1988) was developed for both intact rock and rock masses. To describe the properties of rock masses, correlations between the criterion and rock mass rating parameters were introduced. In the original, updated and modified version, the RMR-system was used. Hoek et al. (1992) stated that, when applied to jointed rock masses, the original Hoek-Brown failure criterion gave acceptable strength values only for cases where the minor principal stress had a significant compressive value. The Hoek-Brown failure criterion (Hoek and Brown 1997) for jointed rock masses is defined by equation.

$$
\frac{\sigma 1}{\sigma c}=\frac{\sigma 3}{\sigma c}+\sqrt{\frac{\sigma 3}{\sigma c} * m+s}
$$

where,

Table 4 Physico-mechanical properties of coal measure formations at GDK No. 10 Incline

\begin{tabular}{|c|c|c|c|c|}
\hline Strata & $\begin{array}{l}\text { Density } \\
\left(\mathrm{kg} / \mathrm{m}^{3}\right)\end{array}$ & $\begin{array}{c}\text { Young's } \\
\text { modulus (GPa) }\end{array}$ & $\begin{array}{l}\text { Thickness of } \\
\text { layer }(\mathrm{m})\end{array}$ & $\begin{array}{l}\text { Poisson's } \\
\text { ratio }\end{array}$ \\
\hline \multicolumn{5}{|l|}{ Roof } \\
\hline $\begin{array}{l}\text { Medium to fine grained grey sandstone with } \\
\text { Quartz and Felspar pebbles }\end{array}$ & 2186 & 3.71 & 20 & 0.25 \\
\hline Coal with clay and carbonaceous shale & 1500 & 1.98 & 6.5 & 0.22 \\
\hline $\begin{array}{l}\text { Medium to fine grained grey sandstone with } \\
\text { Quartz and Felspar pebbles and mica and } \\
\text { pyritic laminae at places }\end{array}$ & 2257 & 4.57 & 11.0 & 0.26 \\
\hline Coal with carbonaceous shale & 1520 & 2.02 & 2.0 & 0.25 \\
\hline $\begin{array}{l}\text { Medium to fine grained grey sandstone with } \\
\text { Quartz and Felspar pebbles, mica laminae, } \\
\text { carbonaceous streaks and pyritic patches }\end{array}$ & 2538 & 4.45 & 25.0 & 0.25 \\
\hline $\begin{array}{l}\text { Carbonaceous sandstone and carbonaceous } \\
\text { shale with thin coal bands and pyritic traces }\end{array}$ & 2036 & 4.9 & 3.0 & 0.25 \\
\hline $\begin{array}{l}\text { Medium grained grey sandstone with Quartz } \\
\text { and Felspar pebbles at places, pyritic traces }\end{array}$ & 2224 & 3.96 & 14.0 & 0.25 \\
\hline Working 3 seam coal & 1390 & 1.92 & 12 & 0.22 \\
\hline \multicolumn{5}{|l|}{ Floor } \\
\hline $\begin{array}{l}\text { Medium to fine grained grey sandstone with } \\
\text { Quartz and Felspar pebbles }\end{array}$ & 2300 & 4.47 & 4.5 & 0.25 \\
\hline Coal & 1370 & 1.89 & 4.1 & 0.22 \\
\hline $\begin{array}{l}\text { Medium to fine grained grey sandstone with } \\
\text { Quartz and Felspar pebbles at places, pyritic } \\
\text { traces }\end{array}$ & 2312 & 5.247 & 11.4 & 0.27 \\
\hline Goaf & 1920 & 0.2 & 10.5 & 0.3 \\
\hline
\end{tabular}


For undisturbed rock

$$
\begin{aligned}
& m=m_{i} e^{(R M R-100) / 28} \\
& S=e^{(R M R-100) / 9}
\end{aligned}
$$

And for disturbed rock

$$
\begin{aligned}
& m=m_{i} e^{(R M R-100) / 14} \\
& S=e^{(R M R-100) / 6}
\end{aligned}
$$

where, $\sigma_{1}$ and $\sigma_{3}$ are principal stresses. $\sigma_{\mathrm{c}}$ is compressive strength of rock.

Safety Factor $=\frac{\frac{\sigma 3}{\sigma c}+\sqrt{\frac{\sigma 3}{\sigma c} * m+s}}{\frac{\sigma 1}{\sigma c}}$

$$
\begin{aligned}
\mathrm{m}_{\mathrm{i}}=\text { Hoek-Brown constant } & =25 \text { for very good quality hard rock masses } \\
& =12 \text { for average quality rock masses } \\
& =8 \text { for poor quality rock masses }
\end{aligned}
$$

\section{Numerical simulation of BG 2B panel of GDK No.10 incline}

The design of pillars in Blasting Gallery (BG) method is of vital importance in optimizing mining operations. The primary requirement for a good and reliable design technique is the ability to represent the actual physical behaviour of the pillar. The model is developed using ANSYS 8.0 for two dimensional plane strain analysis of the panel. The two dimensional, linear elastic and isotropic finite element method is selected to investigate the stress distributions around the pillar in plane strain condition. In this study, 2-D models of different lithology are developed to understand the development of induced vertical stress during depillaring operations under different strata conditions.

In this study, the BG 2B sub-panel of dimensions $135 \mathrm{~m} \times 150 \mathrm{~m}$ (Figure 9) is divided into 12 pillars each with dimensions of $45 \mathrm{~m} \times 37.5 \mathrm{~m}$ by driving level and dip galleries



Figure 9 Plan of BG 2B Panel showing observation pillar. 
Table 5 Salient features of the BG 2B panel

\begin{tabular}{ll}
\hline Seam thickness & $12 \mathrm{~m}$ \\
Goaf height & $17.5 \mathrm{~m}$ \\
Gradient & 1 in 8 to 1 in 10 \\
Grade & D \\
Depth of working seam & $264 \mathrm{~m}$ \\
Size of panel & $135 \mathrm{~m} \times 150 \mathrm{~m}$ \\
Gallery Width & $4.2 \mathrm{~m}$ \\
Gallery height & $3 \mathrm{~m}$ \\
Size of pillar (centre to centre of the gallery) & $37.5 \mathrm{~m} \times 45 \mathrm{~m}$ \\
Angle of line of extraction & $60^{\circ}$ \\
\hline
\end{tabular}

of $4.2 \mathrm{~m}$ width and $3 \mathrm{~m}$ height. The sub-panel has been simulated using ANSYS software. Thereafter, the induced vertical stress contours in the pillars has been observed. The impact of the face advance on pillars and on galleries has also been observed from induced stress contours. The impact of the face advance on the safety factor of the pillar has also been quantified. However, in the simulation study, the mined-out area is also discretized with triangular elements of various sizes. At each stage of depillaring operation, the total mined out area is also simulated. The effect of induced blasting is somewhat included by taking goaf height of $17.5 \mathrm{~m}$ out of which $7 \mathrm{~m}$ is caved-height due to induced blasting. The salient features of the selected sub-panel are presented in Table 5. The physico-mechanical properties of the coal measure formations of GDK No. 10 Incline are presented in Table 4.

The angle of overhanging roof is maintained at $45^{\circ}$ as observed in the field. The falls in the panel are regular so that the distance between the face edge and edge of the caved material is about $2 \mathrm{~m}$ which was observed in the field, also considered in the model. The assumed physico-mechanical properties of the goaf area (Deb et al. 2001) are shown in Table 4. For numerical simulation study, different models have been

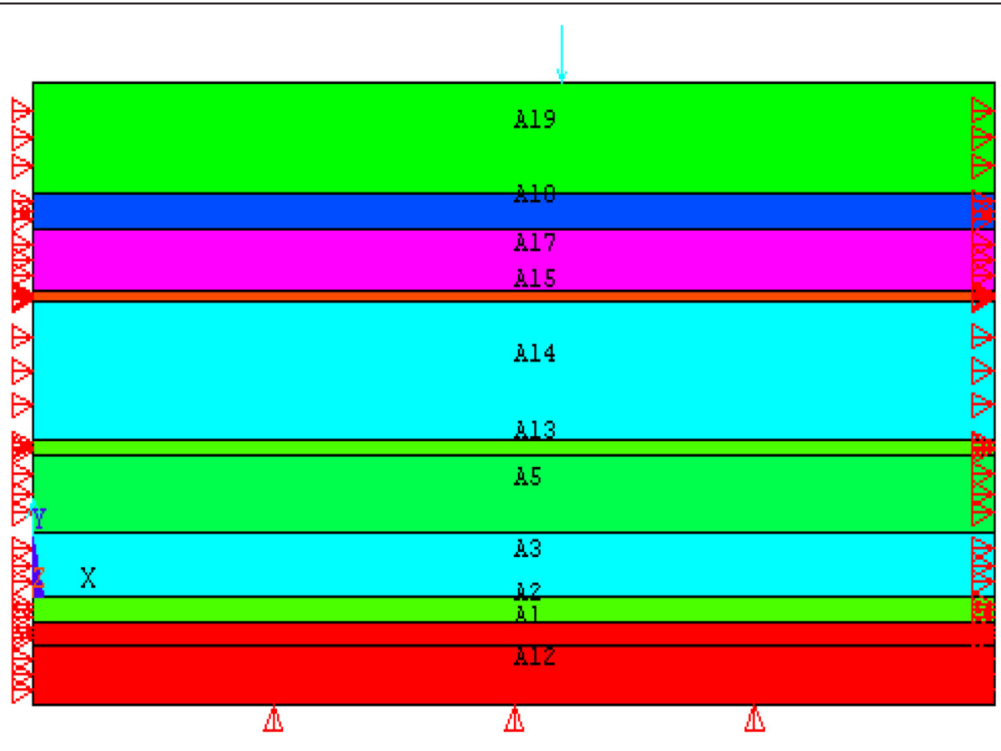

Figure 10 FEM model showing in-situ state of stress and boundary conditions. 




Figure 11 FEM model showing the development of coal seam by formation of pillars and galleries in BG panel.

developed as per actual conditions of development galleries and pillars in coal seam of BG 2B panel.

The FEM analysis is performed for plain strain, with the following boundary conditions. The FEM model boundary along the $\mathrm{X}$ direction is fixed on both sides and the boundary along the $\mathrm{Y}$ direction is free, so that the FEM model is free to move in the vertical direction (Figure 10). The boundary of the FEM model is fixed in $\mathrm{Y}$ direction on bottom side and the boundary along the $\mathrm{X}$ direction is free. A uniform distributed vertical load corresponding to the depth of workings from surface is applied on top of the FEM model. The associated in-situ stress and vertical deformation are then obtained from the finite element modeling results. The FEM models showing in-situ state of stress, boundary conditions, development of pillars and galleries and variation in observed insitu stress are shown in Figures 10, 11 and 12 respectively.

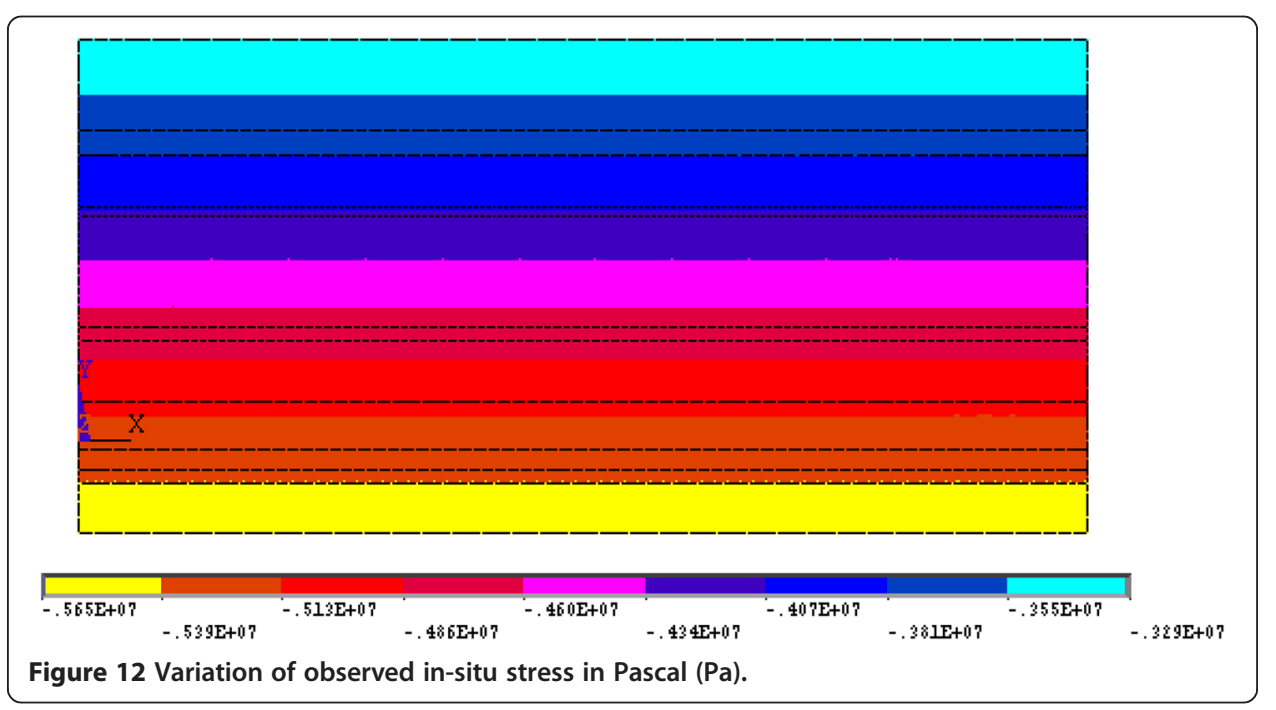




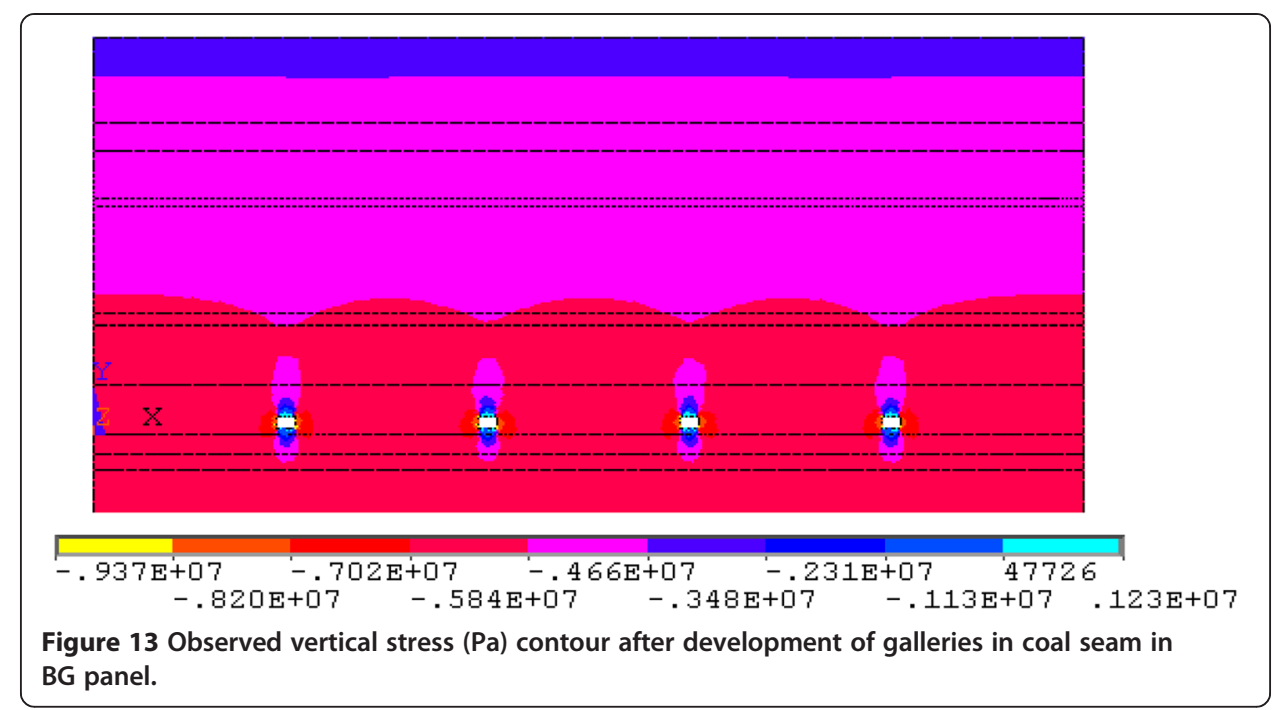

A sequence of two dimensional finite element analysis was carried out and validated with the field instrumentation results. The FEM models from Figures 13, 14, 15, 16 and 17 describe the induced vertical stress contours along advancing line of extraction at various stages of depillaring of coal seam in BG $2 B$ panel. It was observed from the FEM models that the rate of change in mining induced stress and vertical displacement increases with the advance of line of extraction as shown in Figure 18. The magnitude of the induced vertical stress for the highlighted pillar (Figure 9) was ranging from 5.26 to about 16.54 $\mathrm{MPa}$ (5.26 MPa being the in situ vertical stress). The magnitude of the vertical displacement was varying from $151 \mathrm{~mm}$ to $211 \mathrm{~mm}$ (151 mm being the in-situ displacement). Figure 13 shows that the induced vertical stresses are symmetrical

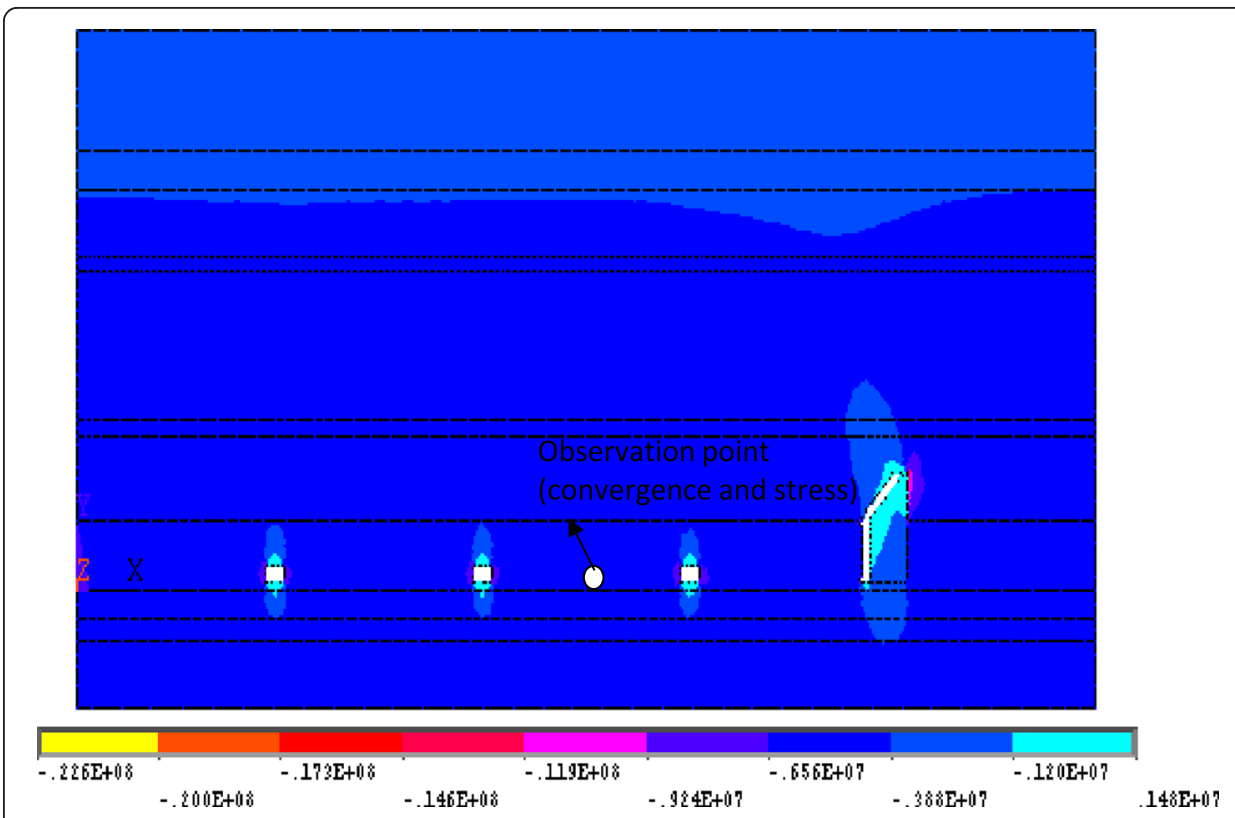

Figure 14 Observed vertical stress $(\mathrm{Pa})$ contour during depillaring of coal seam when $10 \mathrm{~m}$ advance of line of extraction in BG panel. 


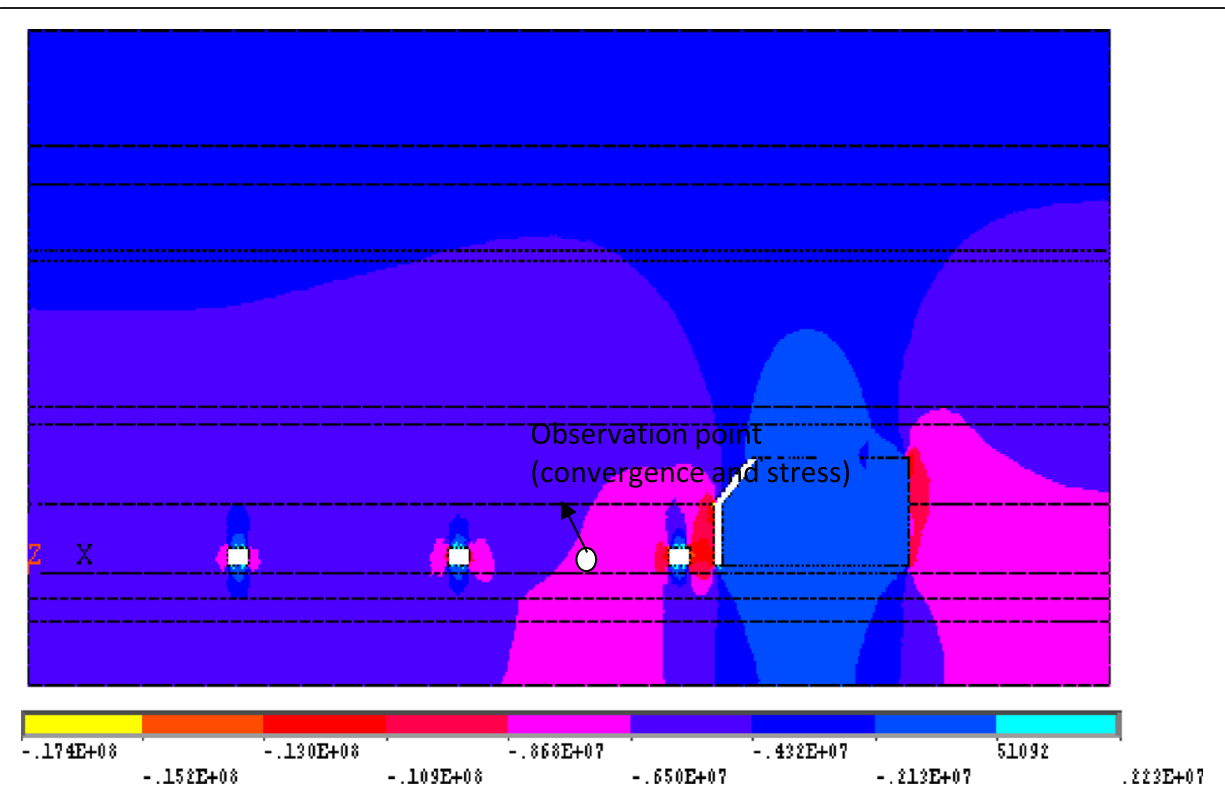

Figure 15 Observed vertical stress $(\mathrm{Pa})$ contour during depillaring of coal seam when $45 \mathrm{~m}$ advance of line of extraction in BG panel.

around the center of the pillar. The corners are more stressed compared to other locations. The edges also experience higher stress values in comparison to the central portion of the pillar, but less than the corner points. The induced stress values at the corners are about $16 \mathrm{MPa}$. As the line of extraction starts advancing towards the pillar under consideration (Figure 9), the induced stress and vertical displacement contours on the pillar vary from symmetrical to asymmetrical. The maximum rate of change in stress was very low $(0.56 \mathrm{MPa} / \mathrm{m})$. When the line of extraction is at about $5 \mathrm{~m}$ from the pillar center, the entire pillar is under influence of goaf where the abutment loading is high. The maximum

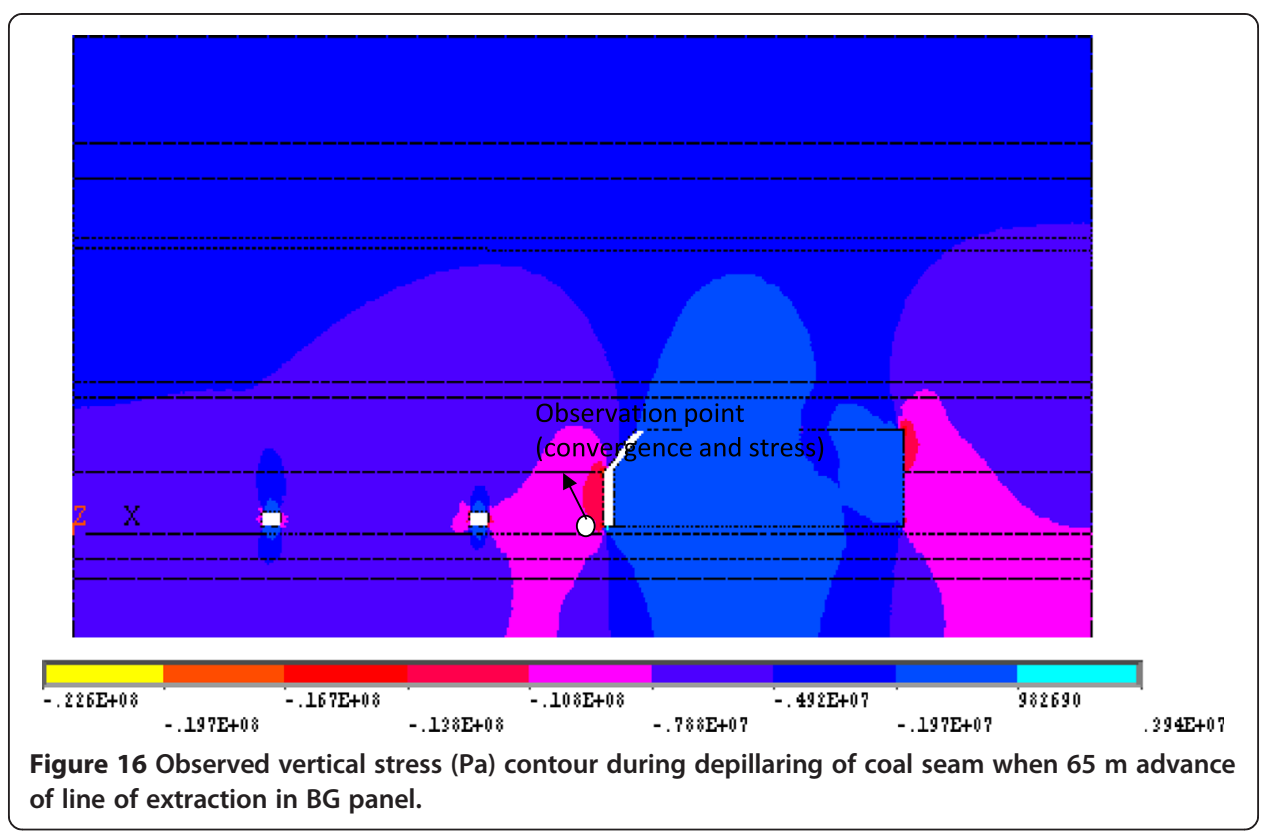




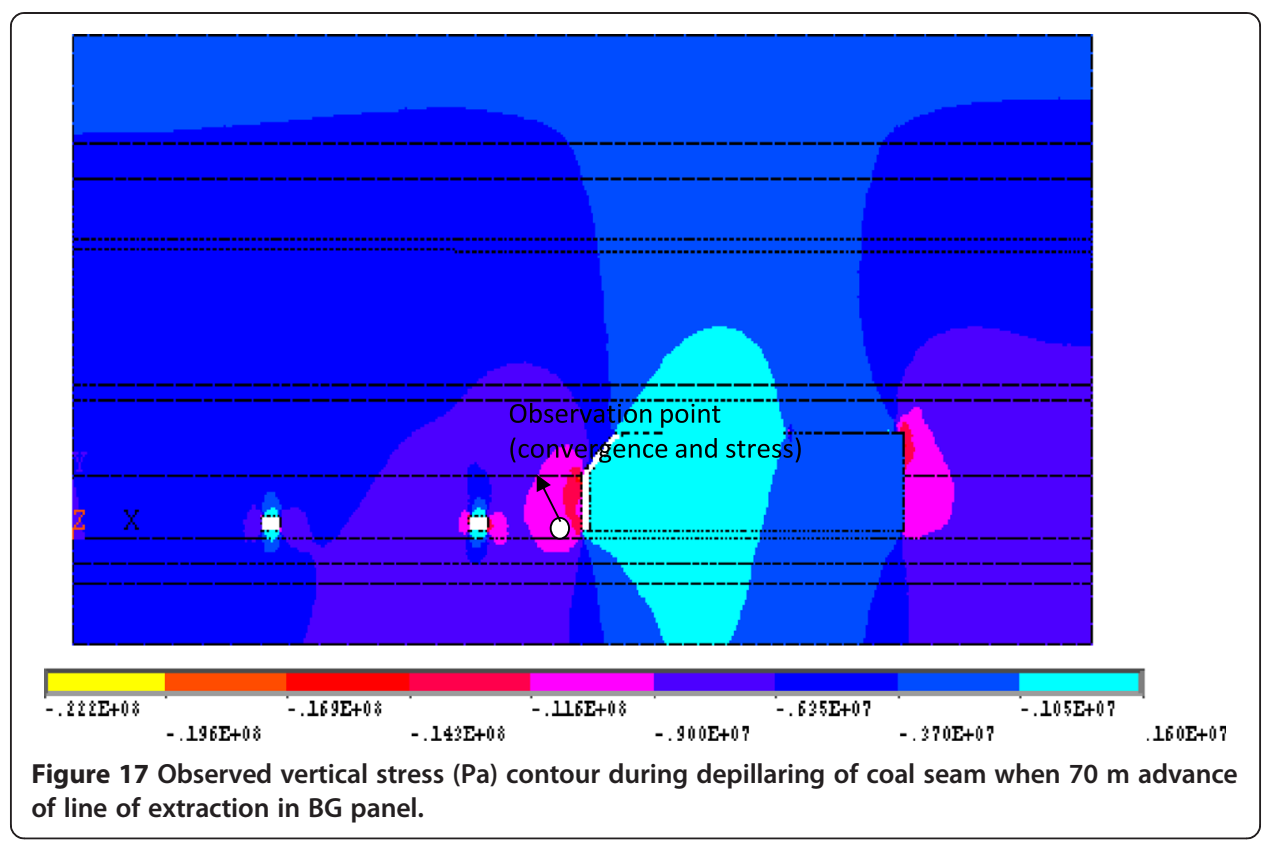

rate of vertical displacement was also low $(1.66 \mathrm{~mm} / \mathrm{m})$ which is below the permissible limit. As the line of extraction advances, the vertical displacement also increases.

\section{Validation of FEM model results}

FEM model results were compared with the actual results obtained from the field instrumentation. As the high density of support system, and big stooks left in the goaf were not simulated and there are falls at regular intervals, the field values are low compared to FEM results. In addition, the artificial lines of fracture induced at regular intervals of 10 to $15 \mathrm{~m}$, may also be attributed to the low values of field results. The rock mass was considered as linear elastic for all models. The predicted vertical displacement using FEM models increases with decrease in the distance of the monitoring point from the goaf edge is shown in the Figure 18. The predicted vertical displacement obtained from FEM analysis is considerably higher than the field results. It is evident from Figure 19, there is little discrepancy in stress between the two curves, indicating that 2D model predicts higher stress than field results. So that the FEM model results are reasonably acceptable with the field results.

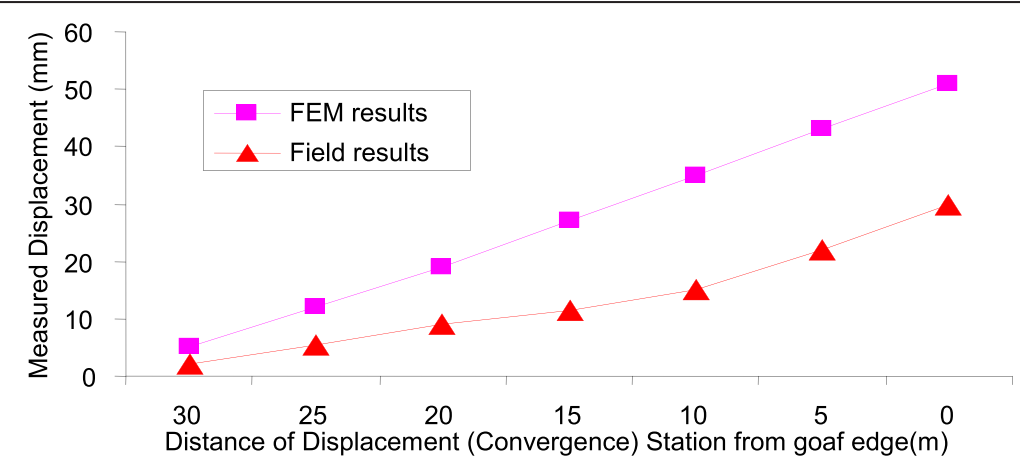

Figure 18 Validation of field results of vertical displacement values with simulated results. 


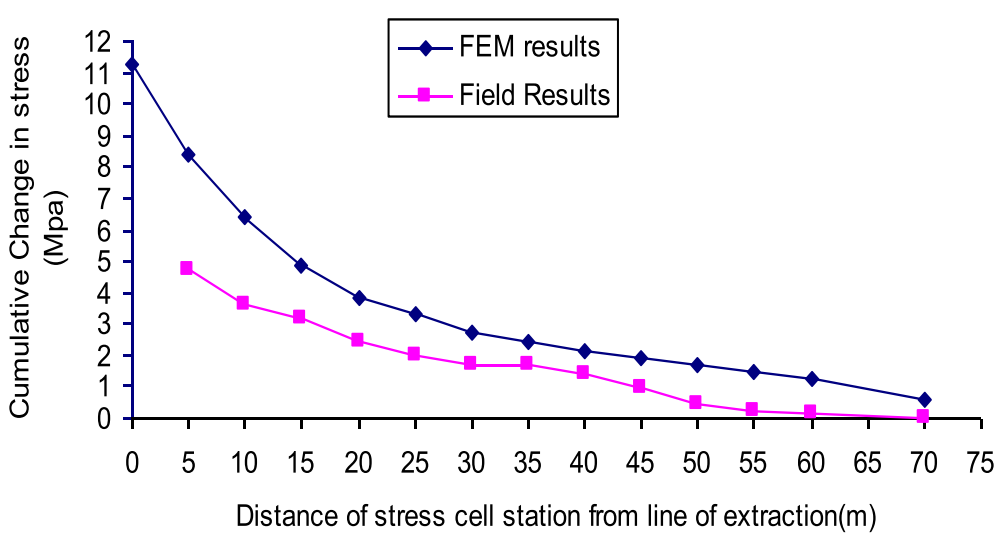

Figure 19 Comparison of field results (BG 2B panel) of stress values with FEM model results.

The safety factor of the pillar is evaluated using Hoek and Brown failure criterion (Hoek and Brown 1997) at different advances of goaf edge. The minor and major principal stresses are obtained from the FEM simulation using ANSYS. The variation of safety factor of pillar with the advance of line of extraction is shown in Figure 20. The maximum safety factor of the observation pillar is 1.7 after the development. The safety factor of the pillar was decreased slowly when line of extraction moves towards center of the pillar and dropped to 1.06 when it advances at the center of that pillar. The rate of reduction of safety factor of the pillar is 0.009 per metre. It indicates that the pillar was stable during its extraction. It was also compared and verified with the field observation results.

\section{Conclusions}

This paper describes the assessment of mining induced vertical stress through extensive field instrumentation to understand the mining induced vertical stress at different locations within the BG 2B panel of GDK No. 10 Incline. Results revealed that the width of abutment zone is estimated to be about 35-40 m from the diagonal line of extraction in the BG panel. Higher stress conditions which are anticipated due to increased depth cover, are not noticed in the panel. This may be due to distressing effect caused as a result of the settled goaf overlying the parting of about $65 \mathrm{~m}$ between 1 and 3 seams.



Figure $\mathbf{2 0}$ Variation of safety factor of the pillar with advance of line of extraction. 
The central portion of the pillar at the roof level experiences the least induced stress; whereas the pillar corners experience the highest stress. It is also observed that as one goes away from the goaf edge, the induced vertical stress and roof deformation decreases. The magnitude of the induced vertical stress was ranging from 5.26 to about 16.54 MPa (5.26 MPa being the in situ vertical stress). The magnitude of the vertical displacement was varying from $151 \mathrm{~mm}$ to $211 \mathrm{~mm}$ (151 mm being the in-situ displacement). It was observed that the induced stress and vertical displacement increase with the advance of line of extraction. The safety factor of the pillar was decreased slowly when line of extraction moves towards center of the pillar and dropped to 1.06 when it advances at the center of that pillar. It indicates that the pillar was stable during its extraction. Results of finite element analysis using ANSYS are validated with results obtained from the strata monitoring instrumentation in the $B G 2 B$ panel at GDK No. 10 Incline, SCCL.

Competing interests

The authors declare that they have no competing interests.

\section{Authors' contributions}

The field studies, laboratory FEM models and presentation of results were carried out by first author. Both authors were analyzed the results and prepared the manuscript. Both authors read and approved the final manuscript.

\section{Acknowledgements}

The authors are obliged to the GM (HRD), SCCL for his permission to publish this paper. The authors are indebted to the mine management of GDK-10 incline for providing help during the field study. The views expressed in this paper are those of the authors and not necessarily of the Institute to which they belong and also express their sincere gratitude to all those who help directly or indirectly in preparing this manuscript.

\section{Author details \\ ${ }^{1}$ Mines Safety (Mines), DGMS, Dhanbad 826001, India. ${ }^{2}$ Department of Mining Engineering, Indian School of Mines, Dhanbad 826004, India.}

Received: 1 June 2014 Accepted: 28 November 2014

Published online: 26 February 2015

\section{References}

ANSYS, Inc. (2003). The ANSYS finite element method, Version 8.0

Deb, D, Ma, J, \& Chugh, YP. (2001). Analysis of the Effects of Weak Floor Strata on Longwall Face Stability Using Finite Element Modeling. Journal of Coal Science and Engineering, 7(1), 1-8.

Dixit, MP, \& Mishra, K. (2010). A unique experience of on shortwall mining in Indian coal mining industry. In Proc 3rd Asian Min Cong, MGMI, Kolkata (pp. 25-37).

Gale, WJ. (1998). The application of field and computer methods for pillar design in weak ground. In Proceedings of the international conference on ground control in mining and underground construction, Wollongong (pp. 243-261).

Hanjura, CL. (2002). Blasting gallery performance and problems in SCCL. Internal report (pp. 1-5). Andhra Pradesh, India: The SCCL.

Hoch, T, Karabin, G, \& Kramer, J. (1991). MSHA's simple technique for predicting the stress distribution in a mine panel. MSHA report (pp. 1-64).

Hoek, E, \& Brown, ET. (1988). The Hoek-Brown failure criterion-a 1988 update. In Proceedings of the 15th canadian rock mechanics symposium, University of Toronto (pp. 31-38).

Hoek, E, \& Brown, ET. (1997). Practical Estimates of Rock Mass Strengh. International Journal of Rock Mechanics and Mining Sciences, 34(8), 1165-1186.

Hoek, E, Wood, D, \& Shah, S. (1992). A modified Hoek-Brown failure criterion for jointed rock masses. In Proceedings of the international ISRM symposium on rock characterisation - EUROCK '92, British Geotechnicall Society, Chester, September, 1 (pp. 209-214).

Singareni, (2003). Internal Reports on BG method in the SCCL.

Jaiswal, A, Sharma, SK, \& Shrivastva, BK. (2004). Numerical modeling study of asymmetry in the induced stresses over coal mine pillars with advancement of the goaf line. International Journal of Rock Mechanics and Mining Sciences, $41(5), 859-864$.

Jayanthu, S. (2005). Strata behavior observations in depillaring experimental panels vis-à-vis applicability of convergence date for working of goaf falls. In International symposium on advances in mining technology and management (pp. 337-341).

Jayanthu, S, Singh, TN, \& Singh, DP. (2004). Stress distribution during extraction of pillars in a thick coal seam. Rock Mechanics and Rock Engineering, 37(3), 171-192.

Majumder, S, \& Chakrabarty, S. (1991). The vertical stress distribution in a coal side of a roadway-an elastic foundation approach. Mining Science and Technology, 12, 233-240. 
Maleki, H. (1992). In situ pillar strength and failure mechanism for US coal seams. In Proceedings of the workshop on coal pillar mechanics and design, Santa Fe, US Bur Mines, Information Circular (IC) 9315 (pp. 73-77).

Mandal, PK, Sarkar, M, \& Singh, TN. (1998). Role of instrumentation and instruments to study the strata behaviour during depillaring operation. The Indian Mining and Engineering Journal, 37(12), 31-38.

Mathur, RB. (1992). Strata mechanics behind the failure of PSLW face at Churcha West Colliery, SECL. In Proceedings of the sixth national symposium, Bangalore, 15-17 October (pp. 59-73).

Sellers, JB. (1997). The measurement of stress changes in rock using the vibrating wire stress meters (pp. 275-288). In: Proceedings of the international field measurements in rock mechanics, Zurich.

Sheorey, PR. (1992). Pillar strength considering in situ stresses. In Proceedings of the workshop on coal pillar mechanics and design, IC 9315, Bureau of Mines (pp. 122-127).

Sheorey, PR. (1994). A theory for in situ stress in isotropic and transversely isotropic rock. International Journal of Rock Mechanics and Mining Sciences, 31(1), 23-34.

Singh, R. (2004). Staggered development of a thick coal seam for full height working in a single lift by the blasting gallery method. International Journal of Rock Mechanics and Mining Sciences, 41, 745-759.

Singh, R, Singh, TN, \& Dhar, BB. (1996). Coal pillar loading for shallow mining conditions. International Journal of Rock Mechanics and Mining Sciences, 33(8), 757-768.

Singh, R, Mandal, PK, Singh, AK, Kumar, R, \& Sinha, A. (2011a). Coal pillar extraction at deep cover: With special reference to Indian coal fields. International Journal of Coal Geology, 86, 276-288.

Singh, R, Singh, AK, Maiti, J, Mandal, PK, Singh, R, \& Kumar, R. (2011b). An observational approach for assessment of dynamic loading during underground coal pillar extraction. International Journal of Rock Mechanics and Mining Sciences, 48, 794-804.

Sjaberg, J. (1983). Design method for stopes and sill pillars with application to Zinkgruvan mine, Central Sweden. Journal of Rock Mechanics and Rock Engineering, 26(3), 253-275.

\section{Submit your manuscript to a SpringerOpen ${ }^{\circ}$} journal and benefit from:

- Convenient online submission

- Rigorous peer review

- Immediate publication on acceptance

- Open access: articles freely available online

- High visibility within the field

Retaining the copyright to your article 